\title{
Kvalitet i journalistik
}

\section{AF FLEMMING SVITH}

Artiklen argumenterer for, at pressens kvalitetskriterier har mistet deres relevans for troværdig journalistik. Det sker i takt med at pressen flytter fokus fra at være "først med det sidste" til "forklaring af det skete“. Pressens kvalitetskriterier er udviklet i en tid, da massemedierne var alene om at formidle nyheder til offentligheden. Journalistik bestod i udvælgelse, sortering og præsentation af kendsgerninger. Kvalitet var hurtighed og præcision. Internet har brudt pressens monopol på videregivelsen af nyheder, og pressen retter fokus mod analyser og fortolkninger med henblik på at afdække sammenhænge, konsekvenser eller løsninger som ikke er observerbare. Dermed bliver journalistikken brugt på domæner, der er domineret af videnskab. Nye journalistiske kvalitetskriterier kan derfor udvikles med udgangspunkt i videnskabens kvalitetskriterier.

Presse og journalistik har gennem mindst et århundrede været uadskillelige. Journalister har anvendt journalistiske metoder til at indfri pressen mål - uanset om de har været publicistiske eller markedsorienterede. Det er også klart, at når pressens mål forandrer sig, drejes journalistikken med. Journalister vil søge efter og anvende de metoder, der bedst egner sig til det arbejde, de udfører. Mange har forsøgt at sætte ord på journalistikkens karakter. Et stort anlagt konsensusprojekt i USA nåede i 2001 frem til: „Journalistikkens formål er at levere præcise og troværdige informationer, som borgerne har brug for i et frit samfund." (Kovach og Rosenstiel, 2001: 17). Projektet har desuden identificeret ni kerneprincipper, som er hæftet på journalistik gennem tiden. 
Her skal fremhæves nummer et, tre og syv:

„Journalistikken første forpligtelse gælder sandheden.“ Begrundelsen er, at „et demokrati hviler på borgere, der er i besiddelse af troværdige, præcise fakta anbragt i en kontekst. Journalistik stræber ikke efter den absolutte sandhed ... Den journalistiske sandhed er en proces, der begynder med at indsamle og få bekræftet fakta. Dernæst forsøger journalister at bibringe fakta en retfærdig og troværdig betydning, som indtil videre er gyldig, men som kan underlægges yderligere undersøgelser. Journalister skal være så åbne som muligt omkring deres kilde og metoder, så modtagerne selv kan vurdere informationerne. Selv i en verden med flere informationsleverandører, er præcision fundamentet for alt andet: kontekst, fortolkning, kommentarer, kritik, analyse og debat. Sandheden vil over tid opstå i det forum. Når borgerne møder en stadig stigende informationsstrøm, har de et større behov, ikke mindre, for tydelige kilder som er helliget efterprøvningen af informationer og placering af dem i en kontekst.“ (Principles, 2006).

Det tredje princip præciserer dele af det første princip: „Journalistikkens essens er at efterprøve informationer." Begrundelsen for det er, at ,journalister hviler på et professionelt fag ved efterprøvningen af informationer. Da begrebet objektivitet oprindeligt opstod, indebar det ikke, at journalister er subjektive. Det var nærmere et krav om en pålidelig metode til at teste informationer - en gennemsigtig tilgang til bevismaterialet - præcist, så personlig og kulturel forudindtagethed ikke ville ødelægge nøjagtigheden i journalisters arbejde. Metoden er objektiv, journalisten er det ikke. Ved at finde mange vidner, ved at afsløre så meget som muligt om kilderne eller ved at få kommentarer fra forskellige sider er signaler om sådan en standard. Efterprøvningsdisciplinen skiller journalistik fra andre typer af kommunikation som propaganda, fiktion eller underholdning." (Principles, 2006).

Det syvende princip handler om formidling: Journalistik „må stræbe efter at gøre det væsentlige interessant og relevant. Journalistik er historiefortælling med et formål ... Den må balancere mellem hvad læserne ved, de gerne vil have, og hvad læserne ikke ved, at de har et behov for ... Et journalistisk produkts virkning 
måles både på, hvor meget det engagerer sit publikum og oplyser det.“ (Principles, 2006).

Det amerikanske projekt blander principper for presse, journalister og journalistik. De resterende seks principper retter sig da også mere mod vilkår for journalister og presse end mod journalistik: „Den skal først og fremmest være loyal over for borgerne; Dens udøvere må bevare en uafhængighed af dem, de dækker; Den må tjene som en uafhængig overvåger af magten; Den må skabe et forum for offentlig kritik og kompromiser; Den må holde nyhederne dækkende og proportionelle; Dens udøvere skal have lov til at efterleve deres egen samvittighed." (Principles, 2006).

Konsensusprincipperne for journalistik kan koges ned til, at journalistik er præcis formidling af relevante og kontrollerede fakta om virkeligheden sat ind i en kontekst. Principperne rummer ikke blot en beskrivelse af journalistik. De karakteriserer også journalistikkens egenskaber som pålidelige metoder til kontrol af informationer, der lægges åbent frem for modtagerne. Det er journalistiske kvalitetskriterier. De sætter rammerne for tilvejebringelsen af journalistiske produkter, der skal være præcise, sande, interessante og væsentlige.

\section{Journalistikkens indhold}

Det er ikke kun i USA, at den opfattelse af journalistik gør sig gældende. Blandt andet Menneskerettighedsdomstolen skelner mellem faktuelle påstande og værdidomme. Ved værdidomme, der omfatter meninger og vurderinger, stilles ikke særlige krav til dokumentation. Værdidomme har principielt et subjektivt præg, der ikke kan bevises eller modbevises, og der stilles derfor kun krav om, at vurderingerne har en vis faktuel basis. Faktuelle påstande fremstår som kendsgerninger. Fremstillingen er derfor principielt rigtig eller forkert. Her giver det mening at stille krav til dokumentation. Ifølge det juridiske system fremskaffer journalisten dokumentationen ved at leve op til sædvanlige standarder for journalistiske undersøgelser (Jørgensen, 2004: 224). „Direktøren har taget af kassen“ er faktuel, mens „direktørens økonomistyring er elendig“ er en værdidom. „Politikeren er korrupt“ er faktuel, mens „politikeren favoriserer sine venner“ er en værdi- 
dom. På trods af de forskellige kategoriseringer er det ikke muligt at holde faktuelle påstande og værdidomme klart adskilt.

Menneskerettighedsdomstolen har i en række sager slået fast, at der må stilles krav til dokumentation, når journalister fremsætter påstande, der fremstår som kendsgerninger. Dokumentationen fremkommer gennem research, hvor journalisten skaffer og korrekt og præcist formidler citater, informationer og faktuelle oplysninger fra flere uafhængige kilder, men at den journalistiske frihed også omfatter en vis grad af overdrivelse. Ekspertudtalelser kan tjene til dokumentation af de faktiske forhold, men ikke altid. En ekspert, der udtaler sig på et mangelfuldt faktuelt grundlag, som journalisten præsenterer for ham, bidrager ikke til at styrke dokumentationen. Kravet om dokumentation øges, jo nemmere det er at skaffe sikker dokumentation, jo mere alvorlige beskyldningerne er, og jo mindre historien haster. Ved beskyldninger skal den angrebne part have mulighed for at komme til orde og forsvare sig og modsynspunkter skal tages med. Det afgørende for Menneskerettighedsdomstolen er, om journalisten har grund til at stole på oplysningerne, sådan som forholdene er på publiceringstidspunktet. Det er dermed ikke oplysningernes korrekthed som sådan, men derimod journalistens tro på publiceringstidspunktet, der afgør strafbarheden. Journalisten er i god tro, hvis han anser informationen for pålidelig. Hvis journalisten undertrykker oplysninger, fordi de ikke passer ind i vinklingen, mister journalisten sin gode tro (Jørgensen, 2004: 233).

I den juridiske version bliver journalistisk kvalitet et spørgsmål om, hvorvidt indsamlede informationer er gengivet korrekt. Kendsgernings-orienteret journalistik bygger på metodiske arbejdsprocesser som udvælgelse, sortering og præsentation af informationer. Der er udviklet journalistiske metoder til faktakontrol, som blandt andet kildekritik og bekræftelse af informationer fra mindst to af hinanden uafhængige kilder. Metoderne blev udviklet i en tid, da massemedier etablerede offentligheden og pressens rolle blev defineret som agenda for den offentlige debat. Med internet og mobile tjenester er der i det seneste 10 år opstået et utal af kanaler til offentligheden. Hvor medierne tidligere blev opfattet som Gatekeepers, der lukkede fakta gennem ledet til offentligheden, taler man i dag om, at hegnet er væltet (Ko- 
vach, 2005). For massemedierne betyder det, at kendsgerningsformidling er blevet underlagt en helt anden konkurrencesituation end tidligere, hvor medierne ikke længere kan være sikre på at være først med det sidste (Ørskov 2006: 3). Journalister anvender derfor i stigende omfang journalistikken til at analysere og fortolke fakta, så formidlingen forskydes fra fakta til fortolkninger og analyser. Det gælder for eksempel en række ugebreve (blandt andet Mandag Morgen, Ugebrevet A4, Økonomisk ugebrev), men også morgenaviserne har ændret fokus med Politiken, der vil give sammenhænge (Seidenfaden, 2006: 2) og Jyllands-Posten, der vil forklare frem for beskrive (Rosenbak, 2006: 1 ).

Det er ikke nyt, at pressen vil servicere offentligheden med analyser, fortolkninger og vurderinger. Det nye er, at analyserne, forklaringerne og vurderingerne skifter placering og status. Pressen har længe både beskrevet og udlagt virkeligheden. Den skelner mellem meninger, der kommer til udtryk i kommentarer og ledere, og det journalistiske indhold. Samme skelnen mellem informationskanal og meningsdanner fremførte Medieudvalget i 1996 (Medieudvalget, 1996). Distinktionen mellem meninger og journalistik fremgår også af mediernes organisering, hvor ansvaret for meninger og journalistik oftest er adskilt og hører under forskellige redaktører. Sådan en skelnen giver kun mening, hvis den samtidig indebærer, at der er forskel på meninger og journalistik. Pressen har traditionelt fremsat værdidomme eller vurderinger i meningsspalterne og bragt faktuelle kendsgerninger i nyhedsspalterne. Det fortsætter den med. Nu blot med den tilføjelse, at de faktuelle kendsgerninger bygger på en anden form for faktualitet. Frem for beskrivelser bygger den i højere grad på journalistiske slutninger, der ikke er håndfast dokumentation for. En forklaring er en påstand om sammenhæng mellem mindst to forhold. Sammenhængen kan være en faktuel kendsgerning, men er det ofte ikke. Sammenhængen bygger på analyser og fortolkninger, der sandsynliggør en sammenhæng, men faktuel i den traditionelle journalistiske forstand er den ikke.

Den post-modernistiske humanistiske videnskab vil stille sig tvivlende overfor pressens forhold til begrebet kendsgerninger. Men socialkonstruktivismen skelner også mellem værdidomme og faktuelle påstande. Modtagerne opfatter værdidomme og fak- 
tiske tekster forskelligt. Pressens journalistiske produkter bliver læst med en læsning, der forholder sig kildekritisk til fremstillingen, dvs. en såkaldt faktiv læsning. „Faktiske tekster er non-fiktive tekster, dvs. de ikke i første omgang skal underlægges en symbolsk tydning, selv om det perspektiv også kan anlægges, men derimod læses som en metonymisk repræsentation, hvor nogle elementer repræsenterer en helhed - et stykke virkelighed.“ (Fibiger, 2005: 14). Den socialkonstruktivistiske medieforskning ser journalistiske produkter som repræsentationer af virkeligheden, men med konsekvenser for opfattelsen af den virkelighed, de beskæftiger sig med. „Inden for forskningen i medier ses medietekster heller ikke blot som afspejlinger af en uden for teksten eksisterende virkelighed, men som repræsentationer, der er med til at konstruere virkeligheden gennem kulturelt specifikke betydninger, som disse repræsentationer tillægger verden. Fokus er på de komplekse processer, hvorved betydninger skabes og ændres i medieproduktion, -distribution og -konsumption.“ (Schrøder og Phillips, 2005: 276).

En moderat socialkonstruktivistisk opfattelse indebærer, at journalister medkonstruerer virkeligheden gennem deres journalistiske produkter. Med journalisters analyser og forklaringer øges det konstruktive element i de journalistiske produkter, selv om de formentligt fortsat vil blive opfattet som virkelighed, altså som faktuelle kendsgerninger. Forskellen på pressens faktiske forklaringer og meningsforklaringer ligger med andre ord i den måde, de opfattes på af publikum, der sidestiller de faktiske forklaringer med virkelighedsbeskrivelser eller afspejlinger af virkeligheden.

Spørgsmålet er, hvordan pressen konstruerer de forklaringer, der antages at være virkelighedsbeskrivelser? Hvilke kvalitetskriterier skal de journalistiske forklaringer leve op til?

På leder- og kommentarplads er der ikke tradition eller behov for at dokumentere de fremsatte vurderinger. Analyser og forklaringer følger ikke samme dokumentationslogik som de faktiske tekster i de redaktionelle spalter med blandt andet kildeciteringer. Det kan blandt andet skyldes, at det i juridisk termer handler om værdidomme, der ikke skal føres bevis for. De samme forklarings- og vurderingsskabeloner er også taget i brug i de faktiske 
tekster. „Nyhedsanalyse“ i dagspressen er en genre, der fremtræder som virkelighedsafspejlinger, men som mangler dokumentationslogikken fra de faktiske tekster. Oftest fremstår de uden andre kilder end den journalistiske skribent. Det kan skyldes mangel på forklaringsskabeloner til faktiske tekster i journalistikken, at den udokumenterede journalistiske forklaring har vundet indpas. I forhold til forklaringer i faktiske tekster virker de udviklede kvalitetskriterier og kvalitetskontrollen, der er rettet mod beskrivelse af kendsgerninger, som utilstrækkelige til at sikre forklaringernes kvalitet.

Ikke så underligt må det amerikanske konsensusprojekt konstatere, at „behovet for professionelle metoder er ikke altid erkendt eller ført ud i livet. Mens journalistik har udviklet forskellige teknikker til at fastslå fakta, har den for eksempel ikke gjort så meget for at udvikle et system til at teste pålideligheden af journalistiske fortolkninger." (Principles, 2006).

\section{Videnskabens kvalitetskriterier}

Mens det er forholdsvis nyt, at pressen sætter mere komplekse forklaringer i centrum, så har det næsten altid været sådan i videnskaben. „Samfundsvidenskabelig forskning har som mål at udvide den menneskelige erkendelse af de samfundsmæssige livsvilkår, at bidrage til at danne grundlag for en forbedring af menneskenes levekår eller at danne grundlag for kritik af myndigheders, virksomheders og gruppers adfærd.“ (Statens Samfundsvidenskabelige Forskningsråd, 2002). Tilsvarende kan det frit efter Medieudvalget formuleres: ,Journalistik har som mål at etablere meninger og viden om de samfundsmæssige livsvilkår, at bidrage til at danne grundlag for deltagelse i beslutningsprocesser eller at danne grundlag for kritik af myndigheders, virksomheders og gruppers adfærd." (Medieudvalget, 1996). De to fags mål er altså fælles om at fremhæve de samfundsmæssige vilkår, et offentligt videngrundlag og en kritisk tilgang. Men mens videnskabens særlige mål er erkendelse, altså at skabe ny viden, der bedre forstår og forklarer verden, har det været journalistikkens mål at bringe informationer videre. Med pressens etablering af analyser og forklaringer bevæger den sig ind på videnskabens 
domæne. Det betyder samtidig, at pressen kan søge inspiration i videnskaben, når de mangelfulde journalistiske kvalitetskriterier skal udbygges.

Forskellige traditioner inden for videnskaben har forskellige kriterier for, hvad kvalitet er. To af de almindeligste begreber er validitet og reliabilitet. Oprindeligt blev de anvendt til at vurdere målingers pålidelighed og gyldighed i indsamlingsfasen.

Reliabilitet oversættes med pålidelighed, og den viser sig ved, om gentagne undersøgelser vil give samme resultat. Reliabiliteten bestemmes af, hvordan indsamlingen er foretaget (Hellevik, 2000: 183). Det handler om nøjagtighed og præcision i indsamling og konstruktion af data, hvor tilfældige fejl kan opstå. Hvis en undersøgelse har lav pålidelighed, svækker det samtidig undersøgelsens validitet. Validitet oversættes ofte med gyldighed, relevans eller begge dele (Andersen, 1997: 109). Relevansen gælder anvendeligheden af indsamlede data i forhold det opstillede problem, mens gyldigheden angår, hvor godt data korresponderer med virkeligheden. Korrespondensprincippet er ét af de videnskabens sandhedsprincipper. Hvad sandhed er, er omtvistet, men korrespondensprincippet hævder en overensstemmelse mellem data, resultat og virkelighed.

Reliabilitet og validitet er udviklet i den kvantitativt orienterede forskning, men de er søgt tilnærmet den kvalitative forskning. „Det generelle emne om kvalitetskontrol i empirisk research er således et frugtbart område for teoriudvikling og udveksling mellem forskellige paradigmer. For eksempel er aspekter af validitet og reliabilitet bragt sammen i begreberne pragmatisk eller kommunikativ validitet, der lægger vægt på valideringsprocessen." (Jensen, 2002: 268). Det er bl.a. Steiner Kvale, der argumenterer for, at kvalitetsbegreberne skal dække alle faser i forskningsprocessen herunder også formidlingen (Kvale, 1997: 246). I en diskussion af forskningsinterviewet inddrager han foruden de forskningsmæssige fremgangsmåder to andre perspektiver i kvalitetsvurderingen: modtagerne og nytten. Det giver tre overlappende kriterier med relevans for videnskabelig kvalitet: håndsværksmæssig, kommunikativ og pragmatisk (Kvale, 1997: 236-245).

Håndværksmæssig kvalitet dækker over videnskabens frem- 
gangsmåder. Det dækker over hele det metodiske og teoretiske fundament for at skabe så sikker viden som muligt. Den håndværksmæssige kvalitet fremmes af løbende selvkontrol, og af at valg af fremgangsmåder bestemmes af indhold, formål og teorier. Den håndværksmæssige kvalitet rummer den traditionelle opfattelse af begreberne validitet og reliabilitet. Men for Kvale handler validitet om sandhed (1997: 233), og den kan med et postmoderne videnskabssyn ikke afgøres af forskeren alene, men gennem dialog.

Kommunikativ kvalitet dækker over, hvad andre siger om resultaterne. Her kommer princippet om konsensus i spil. I videnskaben anvendes princippet til at teste holdbarheden af teorier. Når forskere publicerer resultater og de ikke bliver imødegået, betragtes resultaterne som sikre indtil videre. Det vil sige som uimodsagt forskning. „I videnskaben er det afgørende punkt samtalen i forskersamfundet om forholdet mellem metoder, resultater og arten af de udforskede fænomener." (Kvale, 1997: 235). For Kvale er det imidlertid ikke kun et spørgsmål for kollegerne. „Det nye i samfundsvidenskabernes kvalitative forskning: sandheden forhandles i en lokal kontekst. Forhandlingen sker mellem forskere og de udforskede personer og det almindelige publikum." (Kvale, 1997: 241).

Pragmatisk kvalitet dækker over resultaternes praktiske anvendelighed. Sandheden efter pragmatisk opfattelse er det, der hjælper os til at handle, så vi opnår de ønskede resultater. Pragmatisk validering er således afhængig af den kontekst, den indgår i. Afgørelsen af, hvad der er ønskede resultater, er forbundet med værdier og etik.

Henning Olsen har forsket i kvaliteten af kvalitative forskningsundersøgelser baseret på interview. På den baggrund og i forlængelse af Kvale udfolder han en række kvalitetskriterier og kontrolspørgsmål for henholdsvis håndværksmæssig og kommunikativ kvalitet. Han fremhæver i forhold til Kvale, at videnskabens kommunikative kvalitet i sidste instans afgøres af forskerkolleger (Olsen, 2006: 144). Og han afviser i modsætning til Kvale, at videnskaben kan eller skal have handlingsvejledende kvalitetskriterier. „Problemet er, at pragmatiske kriterier aldrig lader sig formulere på måder, der overskrider politiske modsæt- 
ninger. Selv ikke et sympatisk kriterium om, at 'god' kvalitativ forskning bør være 'pluralistisk', 'demokratisk' og fremme social mangfoldighed, kan formuleres på tværs af politiske opfattelser.“ (Olsen, 2006, 146-147).

\section{Formidlingsorienteret kvalitet}

Med de roller - publicistiske, kommercielle, propagandistiske som pressen indtager følger en række kvalitetskriterier, der mest retter sig mod effekten af de journalistiske produkter. Det handler om den pragmatiske kvalitet, der som Kvale siger, afhænger af værdier og etik, og som Olsen fremhæver ikke kan formuleres på tværs af politiske opfattelser, eller for pressens vedkommende på tværs de sammenhænge pressen indgår i og som den opfatter sig selv som en del af. Pressens roller varier med det omgivende samfund, og det samme gør de normative mål for pressen (Jensen, 1996). I de vestlige demokratier tilskrives pressen en ideel rolle, som forsvarer af ytringsfrihed, kontrol af magthavere, etc.

Spørgsmålet er, hvilke kvalitetskriterier, der retter sig mod pressen, og hvilke der retter sig mod journalistik. Kvalitet handler om beskaffenhed, art og egenskab ved noget (Nudansk ordbog, 1990). En tekst skal have kvalitet ved at være grammatisk korrekt. Grammatisk korrekthed er fastsat ved regler eller konsensus og udgør på den måde en generel kvalitet, der knytter sig til det mål genstanden opfylder. Teksten skal være forståelig og korrekt grammatik fremmer læsbarheden. Men kvalitet eksisterer ikke kun som generel egenskab ved en genstand. Kvalitet knytter sig også til relationen mellem genstand og person. En tekst med grammatiske fejl kan opfylde et behov hos en dansklærer, der anvender den som et eksempel i undervisningen. Tekstens kvalitet knytter her sig til de grammatiske fejl. Den konkrete kvalitet hænger på den måde sammen med forventning og oplevelse eller mellem behov og opfyldelse. Kvalitet afhænger dermed af synsvinkel. I en simpel kommunikationsmodel er der afsender, journalistisk produkt og modtager (McQuail, 2000: 53).

På afsendersiden kan der mindst identificeres tre aktører med kvalitetsinteresser (Nielsen, 1997). Der er journalisten, for hvem kvaliteten ved et produkt hænger sammen med dets prioritering 
og placering i mediet, og med dets håndværksmæssige og æstetiske udformning. Tophistorier påvirker status, ansættelsesforhold og journalistens omdømme, og velresearchede og veltilrettelagte eller velskrevne historier tilfredsstiller journalistens professionelle stolthed. Kvalitetskriterierne kan af journalister opleves som modsætningsfyldte, hvilket illustreres af udtrykket om at „researche en historie ihjel“. Der kan skelnes mellem journalistens karrieremæssige og andre personlige interesser og journalistens faglige interesser. Det kan være andre kvaliteter ved et produkt, som journalisten kan have fælles med andre aktører på et medie. Det gælder nyhedsredaktøren, for hvem kvalitet ved et journalistisk produkt kan måles på, om produktet passer ind i en program- eller artikelmæssig helhed, om hvilke effekter et produkt kan forventes at have eller om produktet giver citater og placerer sig højt på mediedagsordenen.

For mediedirektøren er kvalitet ved et journalistisk produkt, om det sælger aviser/giver lyttere/seere eller om det bidrager til mediets image og annonceindtægter. For public service direktører er kvalitet desuden om et journalistisk produkt lever op til politiske krav og lovfæstede forpligtelser. For mediedirektører kan der skelnes mellem vedkommendes publicistiske og økonomiske interesser. De kan fremstå som modsætninger, men en undersøgelse af amerikanske medier viser en positiv sammenhæng mellem mediers satsning på kvalitet i journalistikken og deres økonomiske situation (Meyer, 2004: 3).

På modtagesiden har aktørerne deres egne kvalitetskriterier, der afhænger af den enkeltes formål med og vurdering af et journalistisk produkt og af det samlede udbud. Der kan identificeres mindst fire interessenter med kvalitetsinteresser på modtagersiden. For politikere, medieeksperter og andre generalister vil kvalitet ved et journalistisk produkt og ved det samlede udbud af journalistiske produkter både være på et generelt og konkret plan. På det generelle plan, der udspringer af forventninger til pressen i et demokratisk samfund, gælder det varetagelsen af ytringsfrihed, nyhedsformidling, kontrol af magtmisbrug, m.m. Pressen forventes at varetage en rolle, der bygger på kvalitet, mangfoldighed, saglighed og upartiskhed. For andre medier er kvalitet ved et journalistisk produkt dets nyhedsværdi, under- 
holdningsværdi og grad af proprietær karakter, der afgør om mediet kan arbejde videre på historien. For involverede kilder og parter i en sag er kvalitet ved et journalistisk produkt, om de og sagen bliver fremstillet på en for dem selv tilfredsstillende måde, herunder en korrekt gengivelse af deres synspunkter. For den almindelige nyhedsforbruger er kvalitet ved et journalistisk produkt knytter til konteksten og indfrielsen af forventninger eller behov. Der er utallige forventninger og behov på det individuelle plan, men også kollektive forventninger og behov. Som en tekst forventes at være grammatisk korrekt, og det opleves som en kvalitet, hvis den er det, så vil der være andre fællesnævnere for den almindelige forbruger i forhold til journalistiske produkter. De generelle krav må forventes at tage udgangspunkt i de roller pressen traditionelt udfylder og i regler og lovgivning for pressen.

Det journalistiske produkt står spændt ud mellem adskillige interessenters kvalitetskriterier. Som det fremgår, er der ikke nødvendigvis overensstemmelse mellem aktørernes kvalitetsinteresser.

Det fremgår også, at kvaliteten ved et journalistisk produkt både ligger i produktet selv, i konteksten og produktets relation til andre journalistiske produkter (Schultz, 2005: 201). Kvalitet ved produktet udspringer af de mange interessenter på både afsender- og modtagersiden, der har berettigede kvalitetskrav. Det gælder kvalitetskriterier, der udspringer af håndværksmæssig og æstetisk udformning, af redaktører og direktørers ønske om at være dagsordenssættende, af lovgivernes ønske om saglig og upartisk dækning, af de involverede kilder og parters foretrukne fremstilling, af den almindelige nyhedsforbrugers interesse $\mathrm{i}$ at være orienteret og ikke spilde sin tid. Kvalitetskravene til produktet kan i sig selv være modsatrettede. En korrekt gengivelse af involverede parters synspunkter matcher håndværksmæssige kvalitetskrav, men den sikrer ikke, at involverede parter fremtræder i det lys, de selv ønsker. Noget der ofte giver anledning til diskussion af journalistisk troværdighed mellem kilder og medier. Hvilke kvalitetskriterier, der kan tilskrives det enkelte produkt, er ikke klart. Der har været fokuseret på forskellige aspekter, men der har ikke været lavet en generel kvalitetsbestemmelse med videnskabeligt og teoretisk afsæt. 


\section{Journalistisk kvalitet}

Journalistik har været defineret som præcis formidling af relevante og kontrollerede fakta om virkeligheden sat ind i en kontekst. Fokuseringen i pressen på baggrunde, forklaringer og fortolkninger stiller krav til journalistikken, som næppe kan indfries. Frem for at udvikle journalistisk faktuelle forklaringer af forhold, hvor sammenhængen ikke er observerbar, har journalisterne taget forklaringsmodeller og argumentationsformer i brug, som pressen anvender i ledere og kommentarer, og som ikke bygger på samme dokumentationslogik som journalistiske artikler eller faktuel argumentation i hele taget.

Heller ikke de journalistiske kvalitetskriterier, der er rettet mod verificeringen af kendsgerninger, kan sikre holdbarheden af journalistiske forklaringer. Kendsgerninger kan kontrolleres og hviler på korrespondensprincippet om overensstemmelse mellem konklusioner og virkelighed. Fortolkninger og forklaringer kan ikke i samme omfang efterprøves. En udvikling af et bredere journalistisk kvalitetsbegreb kan blandt andet inddrage de tre videnskabelige kvalitetskriterier, hvis udgangspunkt er interviewet. Dimensionerne håndværksmæssig, kommunikativ og pragmatisk gælder ikke for journalistikken i samme omfang. Den pragmatiske kvalitet retter sig fortrinsvis mod pressens mål, mens håndværksmæssig og kommunikativ kvalitet retter sig mod journalistikkens mål, retter pragmatisk kvalitet sig fortrinsvis mod pressen og mere indirekte mod journalistikken.

\section{Journalistikkens håndværksmæssige kvalitet}

Den håndværksmæssige kvalitet ligger i fremgangsmåderne. Forskere har beskrevet og testet metoder til at sikre en videnskabelig standard. Ikke blot beskrivelser, men også forklaringer af ikke umiddelbare sammenhænge. I journalistikken bygger metoder på konventioner frem for faglige normer for, hvordan virkeligheden skal aflæses og rapporteres for at leve op til en bestemt standard. Journalistikken har dårligt nok et entydigt fælles begrebsapparat at støtte sig til (Kramhøft, 2000: 29-31).

Konventionerne har antaget en form, hvor de sikrer en fag- 


\section{Figur 1}

Forholdet mellem de forskellige dimensioner i journalistisk kvalitet.

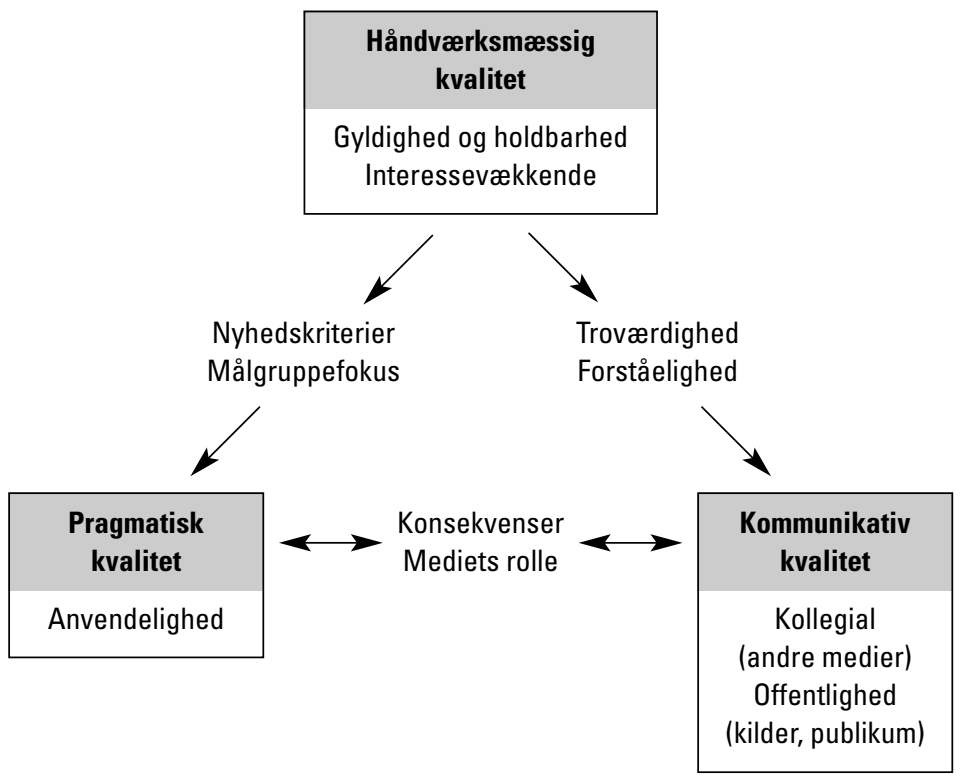

lig standard for validering af kendsgerninger. I det journalistiske fagfællesskab defineres håndværksmæssig kvalitet ved, ,at grundlaget for en god historie med substans er i orden og at den går klart igennem. “ (DJH, 2006: 4)

Substansen sikres ofte tilstrækkeligt med væsentlige kilder, anvendt kildekritisk og som er relevante i forhold til en vinkel. Hvilke retningslinjer det journalistiske håndværk indeholder for generaliseringer og forklaringer er mindre tydeligt. Videnskaben har et utal af (også modsatrettede) kriterier for håndværksmæssige kvalitet. At substansen skal være i orden er et spørgsmål om metoderne gyldighed og holdbarhed. At historien går klart igennem er mere et spørgsmål om at sikre vedkommenheden ved hjælp af journalistiske nyhedskriterier og formidlingsmetoder. 


\section{Journalistikkens kommunikative kvalitet}

Den kommunikative kvalitet handler om andres vurderinger. Videnskaben reserverer primært vurderingen af den kommunikative kvalitet til forskersamfundet og det foregår ved paperfremlæggelser og peer review af videnskabelige artikler. Logikken bag den reservation er, at målgruppen er fagfæller, og at kun fagfæller kan vurdere holdbarheden af ny viden og erkendelse. Journalistikkens kommunikative kvalitet vurderes også af fagfæller, der ud fra faglige kriterier vurderer både konklusionernes gyldighed og holdbarhed og de anvendte fremgangsmåder. I pressen er der ikke peer review og der er ikke en formaliseret evaluering af journalistiske produkter, der giver basis for en kvalitetsvurdering af de enkelte produkter. Men der foregår en løbende evaluering af den journalistiske arbejdsproces mellem producerende og redigerende journalister. Evalueringen afhænger af de tidsmæssige rammer og af karakteren af det journalistiske produkt. Udredende produkter evalueres generelt mere end refererende produkter, men begrænsninger i pressens tid og ressourcer giver i almindelighed ikke muligheden for kvalitetsprocedurer i stil med videnskabens. Det er den ene grund til, at journalistiske produkters kommunikative kvalitet ikke alene kan afgøres af journalistiske fagfolk. Den anden begrundelse ligger i, at pressen pr. definition er anvendelsesorienteret, og at målgruppen for den pragmatiske kvalitet er den brede offentlighed eller segmenter af den. Kan vi overhovedet afgøre journalistisk kvalitet uden at medtænke målgruppen? Journalistik er ikke kunst, der kan tillade sig at lade hånt om publikums opfattelse og forståelse af et værk. Stor kunst, lyder det fra anmelderen, mens publikum intet fatter. Journalistik er underlagt anvendelseskriteriet, hvilket indebærer, at den i det mindste skal forstås af sit publikum. Det duer ikke, hvis alle journalistiske fageksperter stempler noget som journalistisk kvalitet, hvis det misforstås i offentligheden.

I journalistik handler den eksplicitte kommunikative kvalitet om dementier, berigtigelser og kommenterende debatindlæg, og opfølgning på andre medier med eller uden direkte reference. Citeringer opfattes som krediteringer i pressen (Schultz, 2005: 138). Den implicitte kommunikative kvalitet afgøres i kommunika- 
tionen mellem læsere, seere og lyttere. „Man skal ikke tro på alt, hvad der står i avisen“, er et tegn på, at den journalistiske kvalitet vurderes, kommenteres og læses kritisk som en faktisk tekst. Rækken af berettigede kvalitetskrav fra afsendere og modtagere gør journalistikkens kommunikative kvalitet flerdimensional og konfliktfyldt. Det er det journalistiske produkts konkrete kvalitet, der bedømmes - altså kvaliteten for den enkelte. Konsekvensen er, at konsensus ikke kan være et kriterium for journalistikkens kommunikative kvalitet. Journalistiske produkter vil være omgæret af modsatrettede kvalitetskrav og bedømmelser.

Det betyder dog ikke, at den kommunikative kvalitet er uden betydning. Tværtimod. Men et begreb som uimodsagt journalistik vil ikke kunne realiseres som et mål for journalistikken. Fagfællers bedømmelse har været forbeholdt journalistikkens egne fagblade, fordi der ikke i pressen har været tradition for at behandle andre mediers historier ud fra kvalitetskriterier. Der er dog en stigende tendens til, at medier kommenterer åbenlyse fejl i andre medier og efterprøver historierne. TV 2's Triple A historie om bandekriminalitet er et fremtrædende eksempel. Andre kvaliteter ved det journalistiske produkt knytter sig til produktets vedkommenhed i forhold til målgruppe og offentlighed. Er høje læser/seertal udtryk for kvalitet? Det kan det være, hvis interessen mere skyldes produkt end placering i mediefladen.

\section{Journalistikkens pragmatiske kvalitet}

Pragmatisk kvalitet er knyttet til pressens mål. Journalistik har kun pragmatiske kvaliteter i forhold til afsender - pressen - og ikke i forhold til modtagerne. Egner journalistikken sig til at indfri de mål, pressen anvender den til at at nå? Er journalistik den tilgang og de metoder, der under indtryk af arbejdsforholdene i pressen på bedste vis imødekommer pressens behov? Den pragmatiske kvalitet er bærende for pressens demokratiske rolle med oplysning til borgerne om borgere og samfund og kontrol med magthavere. Anvendelseskriteriet er et nyttekriterium i bred forstand, som pressen anvender de journalistiske nyhedskriterier til at indfri. Den pragmatiske kvalitet er anvendeligheden og effekten af journalistiske produkter, altså om de kan bruges og om de 
bliver brugt. For journalist, redaktør og direktør er det pragmatisk kvalitet, når en historie sætter gang i nyhedsstrømmen og giver citater, eller når historien vælter taburetten under en minister. For mediedirektøren er det desuden en kvalitetsmæssig effekt, når historien giver høje seertal, høje klikrater eller store oplag. Journalistikkens udvikling foregår ikke uafhængigt at de mål, pressen stræber efter. Flere medier har søgt at øge effekten hos modtagerne ved at aktivere dem i løsningen af problemer. Det betegnes som public journalism eller aktionsjournalistik (Bro, 2004).

\section{Konklusion}

Presset af ydre omstændigheder som øget konkurrence og internet bevæger dagspressen sig mod et højere ambitionsniveau med flere forklarende historier og færre beskrivende. Når journalisterne griber ned i den journalistiske værktøjskasse, finder de ikke meget om forklaringer, der går ud over det umiddelbart synlige sammenhænge. Det skyldes, at de journalistiske metoder er udviklet i en tid, da det gjaldt om at være først med det sidste. På samme måde er de journalistiske kvalitetskriterier som præcision og hurtighed knyttet til metoder for, hvordan kendsgerninger verificeres og formidles til en bred offentlighed.

Ved mere komplicerede forklaringer står journalisterne over for det problem, at der ikke er udviklet tilstrækkelige holdbare forklaringsmetoder i journalistikken. Det er derfor også uklart, hvilke kvalitetskriterier journalistiske forklaringer skal leve op til.

I videnskaben er kvalitetskriterierne også under ændring. Fra at være koncentreret om indsamlingsfasen og analysefasen udstrækkes kvalitetskriterierne til også at dække formidlingsfasen. Foruden de traditionelle kriterier for hvordan forskning skal foregå, inddrages også opfattelsen og vurderingen af de videnskabelige produkter. Det samme gælder nytten af forskningen, der illustreres af uenigheden om forholdet mellem ,tanke og faktura“. (Regeringen, 2003) Alle tre kriterier - det håndværksmæssige, det kommunikative og det pragmatiske - har relevans for journalistikken. Mens journalistikkens håndværksmæssige kvalitet hovedsageligt retter sig mod verificering af kendsgerninger, 
indeholder videnskab retningslinjer for forklaringer. De kommunikative kvalitetskriterier er meget relevante for pressen, fordi journalistik modsat videnskab er formidlingsorienteret, så kollegernes, kildernes og offentlighedens vurdering virker uomgængelig. Mange aktører med modsatrettede interesser gør det imidlertid generelt vanskeligt at opnå konsensus om den kommunikative kvalitet.

Ikke mindst den pragmatiske kvalitet er vigtigt, fordi den gør det muligt at skelne mellem kvalitetskriterier for pressen og for journalistikken. De ønskede effekter, altså nyttevirkningen eller anvendeligheden, af journalistiske produkter må fortrinsvis være et spørgsmål for pressen og de mål den har sat sig. Deraf følger også, at kvalitetskriterier for nytten fortrinsvis må rettes mod pressen og ikke mod journalistikken. Journalistisk kvalitet må tage udgangspunkt i kvalitetskriterier, hvis formål er at sikre holdbare og vedkommende fakta, forklaringer og fortolkninger.

\section{REFEREN CER}

Andersen, Ib (1997). Den skinbarlige virkelighed, København: Samfundslitteratur.

Bro, Peter (2004). Aktionsjournalistik, Odense: Syddansk Universitetsforlag.

DJH (2006). Generelle hovedopgaveregler, september 2006, Danmarks Journalisthøjskole, Århus.

http://www.djh.dk/StudiePDF/HORegler.pdf

Fibiger, Johannes (2005). „Indledning“, pp. 11-19 i Jørgen Asmussen: Faktiske tekster, 2005, Århus: Systime Academic.

Hellevik, Ottar (2000). Forskningsmetode i sosiologi og statsvitenskab, Oslo: Universitetsforlaget.

Jensen, Klaus Bruhn (1996). Borgerlige ord. Modtagernes perspektiv på nyhedsmedierne i den demokratiske proces, Rapport udgivet at Medieudvalget, Statsministeriet.

Jensen, Klaus Bruhn (2002). „The complementarity of qualitative and quantitative methodologies in media and communication research“, pp. 254-273 i Klaus Bruhn Jensen (ed.), A handbook of Media and Communication Research, London and New York: Routledge. 
Jørgensen, Oluf (2004). Det handler om ytringsfrihed, Århus: Ajour.

Kovach, Bill (2005). A New Journalism for Democracy in a New Age, Speech given in Madrid, Spain, February 1, 2005.

http://www.journalism.org/node/298

Kovach, Bill \& Tom Rosenstiel (2001). The elements of Journalism: What

Newspeople Should Know and the Public Should Expect, New York: Three Rivers Press.

Kramhøft, Peter (2000). Journalistik med omtanke, Århus: Ajour.

Kvale, Steinar (1997). InterView. En introduktion til det kvalitative forskningsinterview, København: Hans Reitzel forlag.

McQuail, Denis (2000). McQuail's Mass Communication Theory, London: Sage.

Medieudvalget, (1996). Betcenkning om medierne i demokratiet, Statsministeriet. http://imv.au.dk/smu/demo_medier/idx.html

Meyer, Philip (2004). The Vanishing Newspaper. Saving Journalism in the Information Age, Columbia: University of Missouri Press.

Nielsen, Poul Erik (1997). Kvalitet og magt i TV, TV’s Æstetik, skriftserie, Aarhus.

Nudansk ordbog (1990). Gyldendal.

Olsen, Henning (2006). „Journalistisk anvendelse og vurdering af kvalitative interviewundersøgelser“, i Flemming Svith (red.), At opdage verden, Århus: Ajour.

Principles of Journalism (2006).

http://www.journalism.org/resources/principles

Regeringen (2003). Nye veje mellem forskning og erhverv - fra tanke til faktura-Regeringens handlingsplan, København.

http://videnskabsministeriet.dk/site/forside/publikationer/2003/

nye-veje-mellem-forskning-og-erhverv---fra-tanke-til-faktur/regeringspublikation.pdf

Rosenbak, Steen (2006). Ny erhvervssatsning på papir og internet, Jyllands-Posten, Erhverv\&økonomi, 2.10.2006.

Schrøder, Kim og Louise Phillips (2005). „Diskursanalytisk tekstanalyse“, pp. 275-302 i M. Järvinen og N. Mik-Meyer (red.) Kvalitative metoder i et interaktionistisk perspektiv: interview, observationer og dokumenter, København: Hans Reitzels Forlag.

Schultz, Ida (2005). Bag om nyhedskriterierne, Phd. afhandling, Roskilde: Roskilde Universitetscenter.

Seidenfaden, Tøger (2006). Argang 123, nr. 1: Politiken, 1.10.2006 
64 // JOURNALISTICA $\cdot 3 \cdot 2006$

Statens Samfundsvidenskabelige Forskningsråd (2002). Vejledende Retningslinier for Forskningsetik i Samfundsvidenskaberne.

Ørskov, Stig (2006). Nyheder er mere end blot nyheder, Politiken, 1.10.2006 